\title{
INNOVATIVE FORMS SUPPORTING SAFE METHODS OF WORK IN SAFETY ENGINEERING FOR THE DEVELOPMENT OF INTELLIGENT SPECIALIZATIONS
}

\author{
Anna GEMBALSKA-KWIECIEŃ \\ Silesian University of Technology
}

\begin{abstract}
:
The article discusses innovative forms of participation of employees in the work safety system. It also presents the advantages of these forms of employees' involvement. The aim of empirical studies was the analysis of their behavior and attitude towards health and safety at work. The issues considered in the article have a significant impact on the improvement of methods of prevention related to work safety and aided the creation of a healthy society.
\end{abstract}

Key words: safety engineering, healthy society, preventive care, occupational diseases, management systems of occupational health and safety, human factor, intelligent specializations

\section{INTRODUCTION}

Within the experience developed in recent years in the European Union in stimulating of innovation at national and regional level, there has been a change in the perception of innovation towards creation of the concept of intelligent specialization. Intelligent specializations, taking into account the specificities and traditions of the regions have become a means to improve innovation and the competitive position of the European Union.

In Poland, individual regions implement the concept of intelligent specialization in their innovation strategy. In the case of the Silesian Province for the most intelligent specializations were: energy, medicine and information and communication technologies. In these areas in the coming years there should be focused its enhanced level of innovation in the region [12].

In the intelligent specialization relating to medicine, which is one of the discriminants of the Silesian Province in the country, for reasons of perfection in many areas of prevention, treatment and rehabilitation, attention was drawn to a healthy society. It is defined, inter alia, through health promotion and health prevention. Due to the specifics of the region and its conditions perfectly typing in the strategy of the region associated with the safety management systems in enterprises, especially in coal mines.

In the aspect of a healthy society there are references to the shaping of a culture of prevention and healthy in different aspects of life, including during work - which in the case of the Silesian Province is very important in occupational diseases, mental state and level of distress experienced of employees.

In health promotion and at every stage of prevention there is a big importance of a permanent public education [22].
According to modern concepts of safety management it is recommended to use preventative technical, organizational and psychological action. In addition to existing technical and organizational actions, it has become critically important to equip people with the knowledge, experience, and particularly motivation to make safe behavior and avoid the risk.

Despite a significant reduction in the number of injuries in recent years, our country has one of the highest rates of accidents at work and occupational and civilizational diseases.

The question therefore arises - what action should be taken in order to efficiently effectively achieve improvement in safety performance in the company? The author hopes that the presented study will contribute to getting an answer and support a healthy society.

\section{SAFETY MANAGEMENT AS PART OF BUSINESS MANAGE- MENT}

Methods and techniques of accident prevention has undergone many more changes, determined by beliefs about the causes of accidents. The transition from fatalism to modern accident prevention and safety management was made gradually through learning the causes of accidents occurring and man's role in causing them. But the most important factor in creating the modern principles of prevention of accidents at work was to increase awareness about the possibilities of taking effective preventive measures to prevent human and material losses. Man must first know the nature that surrounds him, so that he can understand that accidents are not due to force majeure fatalistic, but the result of his own mistakes, both possible predictable and preventable.

As you gain information about the causes of accidents, theories and opinions explaining their origins became modi- 
fiable. In the early days it was seen as accidental events or effect of the new technical systems, unpredictable force majeure referred to the latin name: "vis maior". After that it was noticed (Heinrich, Benner) a human intervention in causing accidents and their sequential course $[3,4,11,21]$. This enabled it to build a "chain" model case being recognized as a consequence of errors due to deficit of motivation, knowledge and experience, the effect of specific personality characteristics, health status or excessively difficult tasks in stressful situations $[7,8,9,21]$.

Safety is a condition in which the protected object is free from the impact of threats. In real conditions safety is a desired state (the limit of our aspirations), but very unlikely (elimination of all threats). For this reason, it is necessary to determine the conditions that may be considered as a safe state. The need to define a border is the reason for the development of regulations and guidelines. An example of this is the labor legislation, which establishes working conditions protecting the interests of the employee as a person weaker in relation to the employer [14].

The primary purpose of safety management is to protect the health and life of people - in an efficient and effective manner. This requires the use of appropriate methods taking into account the existing conditions.

According to R. Studenski safety management is a practical and interdisciplinary activity, utilizing knowledge of systems theory, organization and management, accident and disease prevention, psychology and ergonomics in creating safe working conditions and raising the capabilities and motivation of people to follow safety rules at work and outside it [20].

Due to J. Lewandowski safety management is a set function of management, which is critical in defining and implementing security policies in the workplace [13].

Z. Pawłowska writes that the management of occupational safety and health covers aspects of general management that are associated with the development and implementation of work health and safety policies. The efficiency of this management as skillful control of resources, processes and information to achieve the intended results, has a decisive impact on achieved level of the safety and hygiene [17].

According to D. Petersen safety management, in general, consists of: assessing safety status, the creation of programs to reduce the incidence of accidents and professional management of material resources to be spent on mentioned aims, monitoring and correcting the objectives established in the programs of prevention [16]. In a more narrow sense it includes activities related to the analysis, design and monitoring of the safety system, as well as those of its components which have an influence the size of the risk to loss life or health [16].

The mission of the vast majority of companies is to gain a profit or at least achieve the satisfaction of its operations. The activities related to the safety are seen as an additional burden on the company. For this reason, despite verbal declarations of priority of safety over production, safety is on a low position in the hierarchy of priorities when decisions are making in companies. In studies of Gasparski, CEOs of companies were given a list of 12 criteria, which can guide the decision making process [7].

The main priorities: profit, growth of the company, the possibility of capacity utilization, salaries of the crew. The criterion of "work safety" was in 9th place, followed only by: prestige of company, their satisfaction with novelty, recognition of superiors.

The low position of work safety can be explained by lack of knowledge or ability of choice of preventive methods causing reduction of losses resulting from the activation of the threats. Expenditure incurred by employers to complete the legal requirements are considered as an excessive burden on companies. According to Directive 89/391/EWG: "increased safety, improving hygiene and health protection at work is an objective which should not be subordinated to purely economic considerations". Comparing the results of the research, regulations and guidelines it can be formulated the position that effective safety management is not possible without rating the economic impact of lack of security and without forecasts of the likely losses caused by omission of necessary prevention activities.

It is worth emphasizing that more and more mining companies recognizes the need for development and implement modern principles and work safety management systems.

\section{FORMS OF EMPLOYEE INVOLVEMENT IN THE MANAGE- MENT SYSTEM}

According to B. Błaszczyk one can distinguish three levels of participation: co-decision, consultation and informing.

Co-decision is the broadest level of participation. It is characterized by high employee involvement in the decision process. The employee has the opportunity to express their opposition or veto of unfavorable for himself decisions, and his opinion is taken into account in definitive maneuvers [2].

Consultation means "taking advice, mutual consulting" [20] is another level of participation. Employees have less influence on decision making process. Consultations with employees or their representatives "can be for management mandatory or voluntary, and it may be obligatory to consult certain decisions or lock the feasibility of certain decisions in the absence of an agreement reached through consultation" [15].

The final level of participation is to inform, characterized by low impact of the employee on policy decisions and little of its commitment. The company may, as in the case of consultation, be obliged to inform the employee of all decisions taken before they are taken or can be done on a voluntary basis. However, from the point of view of participation, it is important that the employee has been informed.

Levels of participation can be divided also on passive and active forms, which means cooperation and co-decision -making. Within a cooperation, we can specify:

- informing (manifested in the right to obtain information),

- hearing (including complaints and various proposals),

- speaking out (disclosure of its opinion on the topic and counseling).

While in co-decision-making can be distinguished: the right to oppose (possible to veto), the right of consent (approval of decisions accepted by the employee), the right to a common settlement (active participation in problem solving) and the right to exclusive of regulatory (independent decision making). One can also distinguish three main types of participation: 
- full participation - is characterized that each employee has the influence to decision making process. His expressed opinions are taken into account and are reflected in the final decision,

- partial participation - in the organization there are at least two groups of decision-making that have the opportunity to participate in discussions, but the right to take a final decision is only one of them,

- pseudo-participation - a sign of participation here is the need to obtain a person employed by a broad and clear-sounding reasons for such a decision.

Creating the right conditions to enable the development and proper functioning of participatory tools is dependent on several essential conditions which are interrelated.

The first important factor is the recruitment process. When selecting employees one should pay attention not only to their appropriate professional qualifications or experience, but also on the character traits that favor the use of a participatory management style. Among these features, you can specify: desire for independence and freedom of action, willingness to accept responsibility for decision-making process, identification of the aims of the organization, knowledge and experience sufficient to deal with the problem, the experience with previous supervisors causing a positive attitude towards participating style of leadership [19].

Another condition is teamwork, which consists of the "collective efforts aimed at realizing common goals" [1]. Team work must be based on mutual trust between people belonging to the group, positive relationships between supervisors and employees, mutual respect and the recognition that success depends on everyone.

Participation entails a number of changes in the organization, which very often are reluctant received by managers and employees and have a huge impact on management styles practiced in the company. There are several ways aimed at reducing this negative aspect of participation:

- bringing to agree to the changes by employees - to convince them about the benefits of change, involvement of employees in the process of change (real participation),

- encourage new ideas - creating a conditions in the organization, which enable employees divulging their ideas, kindly accepting any ideas coming out from employees and implement solutions signaled by employees,

- facilitate mutual contacts - adequate communication between the groups, cooperation between the groups, the free movement of information,

- tolerance for failure - for the disappointment resulting from failure to avoid reprimands, and in return provide additional tips, talk about the problem disclosed,

- establish clear objectives and ensure freedom of their achievement - in a participatory style of leadership must be present in employees some leeway in making decisions that will enable them to demonstrate their qualifications and skills,

- provide for the recognition - so that employees are aware that their efforts were noticed and appreciated, and all kinds of awards will encourage further involvement in the affairs of the company.

The next condition for the proper development of participation is adequate information and communication sys- tem. Lack of access, or obstruction of access to information can make a huge barrier to solving problems. "Lack of information means in practice no effect on the course of events, hence the defective system of information and communication between organizational units prevent at all the phenomenon of participation" [6]. Communication, however, is necessary to verify and assess the information obtained.

The content and organization of the work is also very important factor in the development of participation. The involvement of employees in the decision-making process is possible in a situation where work performed is not monotonous and routine. In the case of their work, within the imposed procedures, employee performs restorative work. In contrast, when we allow him a freedom of action, there's a creative element in his work.

Another element which has a significant impact on participation is a process of change. People usually complain and comment on the changes introduced. The main reasons for this behavior are:

- habits - employees are comfortable working under conventional conditions where work is a habit,

- conformity - people like to submit to an acceptable working methods and behavior, any changes in the work environment for them suspicious and cause anxiety,

- misunderstanding - as a result of poor communication it can turn out that employees do not understand the changes and believe that their consequences have much to lose,

- threat to its own interests - people rarely believe that changes can bring them any personal benefits, tend to trap negatives changes than its positives,

- rumors - changes are often preceded by all kinds of rumors, gossip, which unfortunately exaggerate the negative aspects of the proposed project,

- lack of engagement - the changes that are imposed on employees and cannot be discussed very often negatively perceived by them, and they show no interest in them [15].

To reduce the resistance of employees that occurres when there are changes, there can be used participatory methods of persuasion.

The last condition for the occurrence of participation is the use and raising professional qualifications and their development. Employees with high qualifications much more frequently and actively involved in decision-making processes, but on the other hand, participatory management style allows a person less qualified their development and the opportunity to demonstrate himself.

\section{THE BENEFITS OF INNOVATIVE FORMS OF EMPLOYEE INVOLVEMENT}

Top management of each organizational unit must realize that "management is simply too important to leave it to the managers and encourage employees to work" $[10,13]$ The term "management" in this context refers both to the entire organization, as well as security issues. All opportunities to engage the employee in the company's affairs, especially those that are associated with safety management, helping to increase the integration of employees with the company and bring many benefits.

Employee participation in decision-making in relation to the safety, increases job satisfaction and makes a person identifying himself with the company. Involving employees 
A. GEMBALSKA-KWIECIEŃ - Innovative forms supporting safe methods of work in safety engineering for the development...

in issues related not only to their daily duties causes them to begin to expand their horizons interests and reflect on the improvement of the prevailing conditions. Knowing that it affects the performance of company gives them satisfaction and willingness to act. However, the fact that the employee wants to get involved in the issues of the organization must obtain from that basis, certain benefits, which often include money, all sorts of praise from the executives, the feeling of recognition, of independence or the possibility of its own development. It should also satisfy the need of subjectivity of employees by giving them rightful place in the organization and take into account their interests in all company dealings [2]. The possibility of co-decision means that workers shape customs and creative behaviors which often implies a non-standard approach to the tasks to be solved.

The company gains thanks to the involvement of employees, because due to participation it increases employee's satisfaction with their work and it translates into efficiency and productivity, and business efficiency. This is evidenced by studies carried out by The European Foundation for the Improvement of Living and Working Conditions (Eurofound) under the EPOC project - "Employee direct participation in organizational change". Project involved 10 European Union countries and was carried out in years 1993-1998. The obtained results confirmed the economic benefits for businesses resulting from the participation of employees. It was found that as a result of the involvement of employees decreased costs (about $40 \%$ of private companies), improved quality (in about $90 \%$ of companies), increase in production (about $40 \%$ of companies), a decrease of cases (about $30 \%$ of companies), or decrease absenteeism (in about $35 \%$ of companies) [18]. To companies received even better results in this area should be aware of the possibilities of reaping the benefits of participation already in carrying out the recruitment process. They should not pay attention only to the education and experience, but also the personality of the candidate. Persons with relevant character traits can be an important link in the development of the company. Summing up the above benefits company can achieve only through properly selected staff we characterized by creative thinking and creativity, which are the basis of innovation activity.

Employee participation in safety management system in addition to the above mentioned benefits has a big impact on improving the functioning of the system. Employee involvement in activities related to health and safety and the possibility of self-determination means that workers identify with the company and the decisions they take. Therefore, should the company develop a participatory system, putting more emphasis on direct participation of employees in case handlers of the system, as they can not only help solve problems but also affect the improved performance of the implemented system.

\section{FINAL CONCLUSIONS FROM THE CONDUCTED RESEARCH}

In this article it was dealt with the analysis of the Safety Management System in the study of the mine by analyzing documentation Safety Management System of company (SMS), analysis of accidents at work in the years 1997-2011, and empirical research in the form of a survey among workers on SMS knowledge, attitudes and commitment to safety and an interview with the Engineer for coal mine safety.

To obtain the necessary information it has been used an anonymous questionnaire containing 20 questions. The survey was carried out in a group of 120 people, they were manual workers, employed under the ground, men. The average age of respondents was on the level of 36 years [5]. $89 \%$ of the received questionnaires be suitable for further elaboration.

The study was conducted in one of the five mines group of Jastrzębska Spółka Węglowa S.A. (JSW S.A.). The principal activities of JSW S.A. and mines belonging to it, is mining, processing and sales of orthocoking coal, which is the main raw material in the production of metallurgical coke [5].

As a result of the research following conclusions were made:

1. A study conducted relating to analysis in company accidents shows that the introduction of Safety Management System has contributed to reducing the number of accidents. Analyses of accidents for the years 19972011 reveals a significant decrease in the number of accidents, with 372 accidents reported in 1997, to 41 cases in 2011 [5].

2. The most common occupational diseases in the studied company is pneumoconiosis and hearing loss. Less common diseases are chronic diseases of the musculoskeletal system, vibration syndrome has been eliminated to individual cases as a result of automation of manual work. At the end of 2012 there were recorded 9 occupational diseases at the mine, with 8 of them are pneumoconiosis and 1 occupational hearing loss. In the case of occupational diseases a declining trend can be observed [5].

3. To reduce the number of occupational diseases occurring in coal mine developed collectively with the Institute of Occupational Medicine and Environmental Health in Sosnowiec, prevention projects. As a result of the collaboration and the trainings, diagnosis and prevention system, the number of occupational diseases related with hearing loss has stabilized.

4. Analysis of documents and interview with the Safety Management Engineer showed that the mine is in Systems Management Occupational Health and Safety to date. In 2011, the Integrated Management System was successfully recertified. Currently Mine has implemented and still uses all the basic standards of the ISO [5].

5. The mine has a procedure for monitoring occupational health and safety, according to which natural hazards are monitored by automated systems using periodic measurements of exposure in the working environment, then they are documented and employees have access to them. Technical threats are monitored during the control and supervision of the relevant jobs with the use of technical documentation documented. Personal threat monitoring is based on behavioral analysis employees over supervision and control of work performed, potentially accidental events, and past accidents at work [5].

6. According to the Safety Management Engineer incidents largely caused by the incorrect behavior of employees (employees often do not understand that their risky behavior endanger others). Therefore, before the adoption of the employee to work sends it at the expense of mine safety training and later preliminary. Usually they held in the form of a lecture, seminar or course. Later, when there are for example, significant legal changes they are sent to the course, lecture or seminar on futher educating practices, which should end with a test of 
knowledge of this subject. However, the Engineer's observations it appears that the majority of future workers ignore this effort for their safety in the future. Prospective employees go on not because they want to work in the mine, but the lack of involvement with them.

7. The mine has implemented Safety Management System, but according to research, half of the workers do not know him, you will need additional training here. If, however, and they will not bring the desired effects, eg. A lack of interest in the topic employees, there are recommended appropriate penalties. It is necessary to develop awareness among the crew that the only employee working safely ie. In accordance with the provisions of OSH can be promoted or get a raise or a bonus

8. Service of Coal Mine Health and Safety Management develop a series of training courses aimed at continuous improvement and improve safety culture among their subordinates. Safety Management System shapes the culture of security, but it is a continuous process and only then can bring in the long term beneficial effects of changes so that the level of accident rates was satisfactory.

9. In the management of safety, most attention must be paid to the man as a subject of any action. Because it is the human factor is the cause of most accidents and other factors often referred to as the labor factor less important, when using new technologies and materials there should be provided a greater security.

10. Only by realizing and then shaping the healthy habits of employees, it is possible to support a creation of a healthy society.

11. In the modern company in creating the desired safety culture must involve all employees, at all levels - without exception. Each employee must actually see the respect and observance of safety regulations for supervision and top management of the mine.

12. According to the empirical research, the mine leaves a lot to be desired in the issue of participation of its employees. The staff are not interested in switching to solving security issues and a rather characterized by passivity. Improving this situation it is necessary and lies with both, the management and crew.

13. It seems necessary to also stimulate a healthy motivation to work safely among the crew, through its activation and implementation of collectively developed solutions aimed at prevention and health promotion in the fight against occupational diseases.

14. The appropriate selection to work and normal process of adaptation of a professional worker. Dedication to him at that time a lot of attention, and the elimination of workers do not comply with the rules and principles of safety and prone to risky behavior.

15. Implementation of the education and activities aimed at reducing distress of employees connected with the nature of work, as well as developing methods for dealing with it. Education associated with a healthy lifestyle.

16. Training relating to health and safety issues should be conducted in a diverse form of communication, in a manner interesting and understandable to a specific recipient. Should involve participants in discussion and problem solving, stimulate their creativity in accordance with applicable regulations. They should respond to the needs of listeners on the subjects and issues. Training always, without exception, should result in a test of knowledge, know how and where possible (depending on discussed topics) practical test of the newly acquired skills.

This article was prepared within the statutory research titled "Production engineering methods and tools for development of smart specializations", work symbol 13/030/BK_16/0024 performed at Silesia University of Technology, Institute of Production Engineering.

\section{REFERENCES}

[1] M. Armstrong. Zarzq̨dzanie zasobami ludzkimi, Kraków: Oficyna Ekonomiczna/Dom Wydawniczy ABC, 2000.

[2] B. Błaszczyk. Uczestnictwo pracowników w zarzqdzaniu przedsiębiorstwami w krajach Europy Zachodniej, Warszawa: Polskie Wydawnictwo Ekonomiczne, 1988.

[3] T.J. Bentley. The Management Services Handbook, London: Holt, Reinhart and Winston, 1987.

[4] C.I. Bernard. The Functions of the Executive, Cambridge: Harvard University Press, 1938.

[5] Internal documents of Hard Coal Mine, KWK Jas-Mos, 2012.

[6] V. Dušak and N. Vrček. „Technologie informacyjne jako niezbędny czynnik skutecznej komunikacji w czasie realizacji projektu", in Zeszyty Naukowe Politechniki Śląskiej (s. Organizacja i Zarzqdzanie), z. 11, 2002, pp. 229-242.

[7] P. Gasparski. „Kadra kierownicza wobec ryzyka zawodowego pracowników”, in Psychologia i bezpieczeństwo pracy, T. Tyszka, Warszawa: Instytut Psychologii PAN, 1992.

[8] A. Gembalska-Kwiecień. „Czynnik ludzki w powodowaniu błędów podczas pracy", in Praca, Zdrowie, Bezpieczeństwo, no. 1, 2005.

[9] A. Gembalska-Kwiecień. „Kultura bezpieczeństwa pracy a wypadkowość", in Ślqqskie Wiadomości Elektryczne, no. 2, 2005.

[10] R. Griffin. Podstawy zarzqdzania organizacjami, Warszawa: Wydawnictwo Naukowe PWN, 2000.

[11] K. Hendrick and L. Benner. Industrial accidents with STEP, New York: Marcel Dekker, 1987.

[12] Krajowa strategia inteligentnej specjalizacji, KSIS, Warszawa, 2013.

[13] J. Lewandowski. Zarzqdzanie bezpieczeństwem pracy w przedsiębiorstwie, Łódź: Wydawnictwo Politechniki Łódzkiej, 2000.

[14] M. Matey. Nowy ład pracy w Polsce i Europie: praca zbiorowa, Warszawa: Wydawnictwo Naukowe SCHOLAR, 1997.

[15] T. Mendel. Partycypacja w zarzqdzaniu współczesnymi organizacjami, Poznań: Wydawnictwo Uniwersytetu Ekonomicznego w Poznaniu, 2001.

[16] D. Petersen. Safety Management - A Human Approach, New York: Aloray Inc., 1988.

[17] Z. Pawłowska. „Zarządzanie bezpieczeństwem i higieną pracy", in Bezpieczeństwo pracy i ergonomia, tom II, D. Koradecka, Warszawa: Centralny Instytut Ochrony Pracy, 1997.

[18] Eurofound. EPOC - New Forms of Work. Can Europe Realize Its Potential? [Online]. Available: http:// www.eurofound.europa.eu/ef/sites/default/files/ ef_files/pubdocs/1998/03/en/1/ef9803en.pdf 
[19] J. Stoner and C. Wankler. Kierowanie, Warszawa: Polskie Wydawnictwo Ekonomiczne, 1996.

[20] Słownik języka polskiego, Warszawa: Polskie Wydawnictwo Ekonomiczne, 1993.

[21] R. Studenski. Organizacja bezpiecznej pracy w przedsiębiorstwie, Gliwice: Wydawnictwo Politechniki Śląskiej, 1996.
[22] Wykaz krajowych inteligentnych specjalizacji, [Online]. Available: http://www.ncbr.gov.pl/ gfx/.../7_wykaz_krajowych_inteligentnych_specjalizac ji.pdf

dr Anna Gembalska-Kwiecień

Silesian University of Technology, Faculty of Organization and Management

Institute of Production Engineering

ul. Roosevelta 26, 41-800 Zabrze, POLAND

e-mail: Anna.Gembalska-Kwiecień@polsı.pl 